\title{
Haplotype diversity of the myostatin gene among beef cattle breeds
}

\author{
Susana Dunner ${ }^{\mathrm{a} *}$, M. Eugenia Miranda ${ }^{\mathrm{a}}$, Yves Amigues ${ }^{\mathrm{b}}$, \\ Javier CAÑón ${ }^{\mathrm{a}}$, Michel GeORGES ${ }^{\mathrm{c}}$, Roger HANSET ${ }^{\mathrm{d}}$, \\ John WiLliams ${ }^{\mathrm{e}}$, François MéNISSIER ${ }^{\mathrm{f}}$ \\ a Laboratorio de genética molecular, Facultad de Veterinaria, \\ Universidad Complutense de Madrid, 28040 Madrid, Spain \\ ${ }^{\mathrm{b}}$ Labogena, 78352 Jouy-en-Josas Cedex, France \\ ${ }^{c}$ Department of genetics, Faculty of Veterinary Medicine, \\ University of Liège (B43), 20 Bd de Colonster, 4000 Liège, Belgium \\ ${ }^{\mathrm{d}}$ Herdbook BBB, 4 rue Champs Elysées, 5590 Ciney, Belgium \\ e Roslin Institute, EH25 9PS Midlothian, UK \\ ${ }^{\mathrm{f}}$ Institut national de la recherche agronomique, \\ Station de génétique quantitative et appliquée, Domaine de Vilvert, \\ 78352 Jouy-en-Josas Cedex, France
}

(Received 11 January 2002; accepted 2 August 2002)

\begin{abstract}
A total of 678 individuals from 28 European bovine breeds were both phenotyped and analysed at the myostatin locus by the Single Strand Conformation Polymorphism (SSCP) method. Seven new mutations were identified which contribute to the high polymorphism (1 SNP every $100 \mathrm{bp}$ ) present in this small gene; twenty haplotypes were described and a genotyping method was set up using the Oligonucleotide Ligation Assay (OLA) method. Some haplotypes appeared to be exclusive to a particular breed; this was the case for 5 in the Charolaise (involving mutation Q204X) and 7 in the Maine-Anjou (involving mutation E226X). The relationships between the different haplotypes were studied, thus allowing to test the earlier hypothesis on the origin of muscular hypertrophy in Europe: muscular hypertrophy (namely nt821(del11)) was mainly spread in different waves from northern Europe milk purpose populations in most breeds; however, other mutations (mostly disruptive) arose in a single breed, were highly selected and have since scarcely evolved to other populations.
\end{abstract}

muscular hypertrophy / myostatin gene / haplotype diversity / beef cattle breeds

\section{INTRODUCTION}

The bovine muscular hypertrophy $(\boldsymbol{m h})$ syndrome has been widely documented since it was first described $[1,17,18,25]$. It occurs at different frequencies in many European cattle breeds. It was first believed that the

* Correspondence and reprints

E-mail: dunner@vet.ucm.es 
syndrome had the same origin and mutation $[8,11]$ until recently. When the gene underlying the trait was identified as myostatin [14,21,24], it was found to have a surprisingly high number of polymorphisms [15]. Some changes at the nucleotide level truncate the protein product resulting in a lack of its expression and in the known muscular hypertrophy phenotype.

In the many cattle breeds in which it appears, the $\boldsymbol{m} \boldsymbol{h}$ phenotype shows differences in intensity probably due to differences in selection pressure maintained during generations on related traits that vary depending on market necessities as well as on management requirements. In particular, many breeders have tried to limit the occurrence of dystocia, which decreases the economical value of the $\boldsymbol{m} \boldsymbol{h}$ phenotype. As a consequence, some breeds which are well adapted to the binary local management and muscular hypertrophy (e.g. Asturiana de los Valles, Parthenaise or Blanc Bleu Belge), show a high frequency of the mutated gene in their population while others have a very low frequency of any mutation (Pirenaica or Bazadaise). Since a large pleiotropic effect is observed, genotype identification of the $\boldsymbol{m} \boldsymbol{h}$ gene is important to avoid difficulties when selection on this gene is practised, whether fixation, elimination or introgression is desired.

Six disruptive mutations were described earlier $[4,15,21]$ in different breeds and explain the most extreme phenotypes. However, some individuals in different breeds do show a phenotype not corresponding to their genotype at the known polymorphic sites.

To analyse all these cases and search all other possible mutations that could explain the different phenotypes, we screened the entire coding region and splice sites for mutations in the gene in a large number of breeds by using the Single Strand Conformation Polymorphism (SSCP) technique. This method makes the detection of previously described mutations easy and enables unknown mutations to be identified in new individuals. All the mutations identified were defined in haplotypes and were later grouped according to their possible link with particular phenotypes. An easy and fast method of genotyping based on an oligonucleotide ligation assay (OLA, [16]) which describes the complete myostatin genotype was used to screen the samples, allowing population analysis at the gene level. The greater the knowledge of this gene, the better the management will be, allowing other genes with smaller effects on muscular development to be identified. This study also used distance information estimated from the nucleotide differences between haplotypes to reconstruct the evolutionary history of the bovine populations, allowing the earlier hypothesis on the origin of muscular hypertrophy in Europe to be tested.

\section{MATERIALS AND METHODS}

\subsection{Animals}

A total of 678 animals from 28 breeds were used in this study; 4 Spanish breeds: Asturiana de los Valles (AV), Asturiana de la Montaña (AM), Rubia 
Gallega (RG) and Pirenaica (PI); 12 French breeds: Aubrac (AU), Bazadaise (BZ), Blonde d'Aquitaine (BA), Bretonne Pie Noire (BR), Charolaise (CH), Gasconne (GA), Inra95 sire line (IN95), Limousine (LI), Maine-Anjou (MA), Normande (NO), Parthenaise (PA) and Salers (SA); 2 Belgian breeds represented by the Blanc Bleu Belge Mixte (BBB mixte) and by the Blanc Bleu Belge culard (BBB); 9 British breeds: Aberdeen Angus (AA), Ayrshire (AY), British Shorthorn (BS), Devon (DE), Galloway (GL), Hereford (HE), Traditional Hereford (HT), Longhorn (LH) and South Devon (SD) and 1 Italian: Marchigiana (MG). Amongst these individuals, a total of 505 individuals belonging to AV, AM, RG, PI, BZ, CH, GA, IN95, MA, and PA were previously phenotyped according to the Euromh (BIO4-CT98-0421) scoring system (Ménissier, unpublished results). Briefly, all animals were scored for three phenotypic traits: (1) general body conformation (animal general classification, muscling depth, back width); (2) muscle expression (shoulder muscle depth, longissimus dorsi and great dorsal hypertrophy, thigh circumference, croup slope, inter-muscular definition) and (3) hypertrophy associated traits (bone size, tail position, posture and gait, abdomen shape, skin type). Each class was scored from 0 (no hypertrophic signs) to 2 (high double muscling) and a general mean note called the Phenotypic score (PS) was produced. Although phenotypes often differ dramatically from one breed to another, this phenotype scoring allowed different sets of animals that belonged to four different categories $(0-0.5 ; 0.5-1 ; 1-1.5 ;>1.5)$ to be chosen for each breed.

\subsection{SSCP}

All 678 individuals were analysed with the SSCP technique, aimed at detecting all mutations present and not described, for posterior sequencing. DNA was extracted according to standard methods $[19,32]$. The SSCP (single stranded conformation polymorphism) $[29,30]$ technique was used to allow sequence variants to be detected from migration shifts in PCR amplified fragments of the gene. PCR primers were designed to produce eight partially overlapping fragments of different lengths (238 to $419 \mathrm{bp}$ ) (Fig. 1) based on previous information $([12,13,15]$; M. Georges unpublished information). The eight fragments were generated from four different duplex PCR combinations of primers (Tab. I) in a $50 \mu \mathrm{L}$ total reaction volume containing $200 \mu \mathrm{M}$ dNTPs, $2 \mathrm{mM} \mathrm{Cl}_{2} \mathrm{Mg}, 1 \mathrm{U}$ Taq (Biotools), 5 to $20 \mathrm{pmol}$ of each primer and $100 \mathrm{ng}$ DNA with the following PCR conditions: $94^{\circ} \mathrm{C} 1^{\prime}, 55^{\circ} \mathrm{C} 1^{\prime}$ and $72^{\circ} \mathrm{C} 1^{\prime}$ during 30 cycles initiated with $5^{\prime}$ denaturing $\left(94^{\circ} \mathrm{C}\right)$ and $5^{\prime}$ final extension at $72^{\circ} \mathrm{C}$. Three microliters of each PCR sample were mixed with an equal volume of denaturing loading buffer ( $0.05 \%$ xylene-cyanole, $0.05 \%$ bromophenol blue, $5.5 \mathrm{mM}$ EDTA, $\mathrm{pH}$ 8.0, in deionised formamide), were heat-denatured at $95^{\circ} \mathrm{C}$ for $5 \mathrm{~min}$, and were snap-chilled on ice. The samples were then loaded 


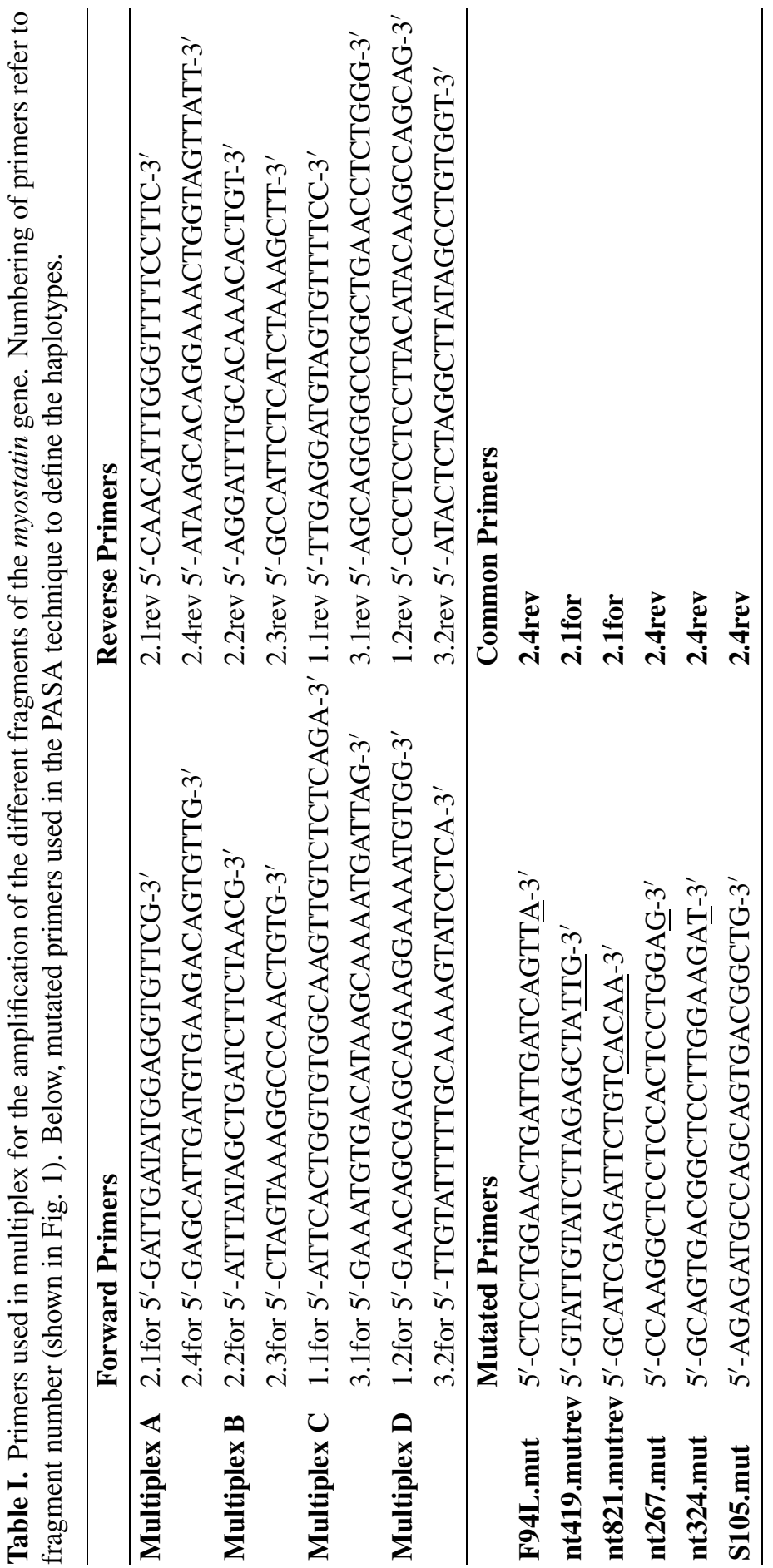



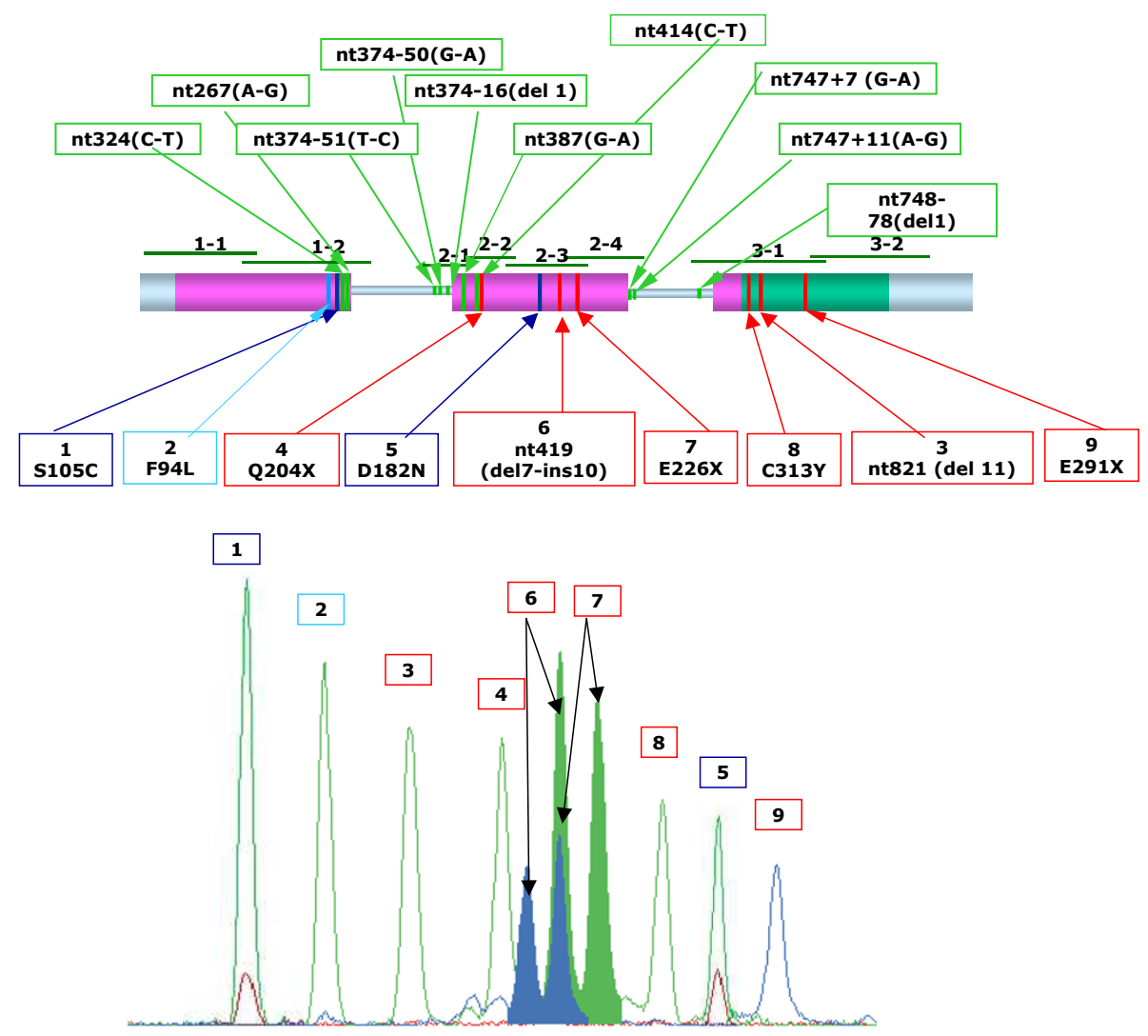

Figure 1. Myostatin gene. The top of the figure shows the three exons of the gene with the different mutations (silent are green, missense but not disruptive are blue and disruptive are red). The bottom of the figure shows the OLA image of an individual obtained either in a ABI PRISM 310 or 3700 automatic sequencer. Green peaks refer to wild type, and blue peaks refer to mutated alleles in the ligand. Red peaks belong to the TAMRA size standard. In this example, the individual is wild type for all mutations but also shows the mutated alleles for nt419(del7-ins10) and E226X, so it will be considered as double heterozygote for these two mutations, but wild homozygote for the rest. The numbers on the peaks refer to the mutation involved, indicated in the squares.

onto non-denaturing polyacrylamide gels using the Penguin Dual-Gel Water Cooled Electrophoresis System (OWL Scientific, Woburn, MA). A cooling device (Cooling Plus 8-30e, Heto-Holten A/S, 3450 Allerød, Denmark) kept the apparatus at the constant chosen temperature during the electrophoresis. Several variables were tested in order to achieve an optimum separation of the alleles: acrylamide concentrations (from 6 to 16\%), acrylamide bis ratio (19:1, $29: 1,100: 1)$, glycerol level $(0 \%, 5 \%$ or $10 \%)$, electrophoresis temperature 
(from 6 to $26^{\circ} \mathrm{C}$ ) and buffer conditions $(0.5 \mathrm{X}$ or $0.6 \mathrm{X})$. The bands were visualised by silver-staining according to the method of Bassam et al. [2] with minor modifications [3]. Silver-stained allele-specific SSCP bands were excised from the gel, placed in $100 \mu \mathrm{L}$ of distilled water and subjected to $95^{\circ} \mathrm{C}$ for $15 \mathrm{~min}$, two freezing $\left(-70^{\circ} \mathrm{C}\right)$ and thawing cycles and then centrifuged at $10000 \times g$ for $2 \mathrm{~min}$. Five microliters of the resulting solution were PCR re-amplified in $50 \mu \mathrm{L}$ reactions using the corresponding primers of the excised fragments. The PCR re-amplified allele-specific SSCP bands were purified and sequenced in an ABI 310 DNA Sequencer using the ABI Prism Dye Terminator Cycle Sequencing Ready Reaction kit (Perkin Elmer BioSystems) according to the manufacturer's instructions and were compared against known alleles for the bovine myostatin gene (GenBank Accession n ${ }^{\circ}$ AF019620 and AF019761, M. Georges, unpublished results).

\subsection{OLA reactions}

The nine mutations which were chosen in this study (Fig. 1) changed an amino-acid and were previously screened or identified in this study $[4,15$, 21]. For this purpose, the primers were designed to allow strand ligation to occur when the two probes matched exactly and thus producing a differentiated result which was easy to interpret. The test was based on the simultaneous amplification of the three myostatin exons using prior primers and conditions detailed elsewhere [28].

\subsection{Haplotype definition}

PCR amplification of specific alleles (PASA, [36]) was performed to generate fragments covering two exons (up to $2 \mathrm{~kb}$ ). Six different allele specific primers (Tab. I) were necessary to solve the combinations of variants on a single chromosomal segment. Sequencing of the PCR fragments enabled the different haplotypes, found among the European breeds studied, to be defined. The evolutionary history between the different haplotypes was then analysed using the Kimura distance [23] and their graphic representation through the Neighbour Joining method.

\section{RESULTS}

Optimal SSCP electrophoresis conditions were obtained using a 12\% 100:1 acrylamide-bis acrylamide ratio (in all cases but for multiplex D, where $16 \%$ gave the best results), $10{ }^{\circ} \mathrm{C}$ constant temperature $\left(24^{\circ} \mathrm{C}\right.$ for multiplex D), $5 \%$ glycerol and $200 \mathrm{~V}$ constant voltage (4 W constant power for multiplex D). Electrophoresis was performed on both multiplex A and $\mathrm{B}$ for $7 \mathrm{~h}$ and on multiplex $\mathrm{C}$ and $\mathrm{D}$ overnight $(17 \mathrm{~h})$. These conditions optimised the discrimination 
between the control alleles, allowing clear patterns corresponding to all but one (nt748-78(del1)) polymorphism described to date (figures not shown) [26,27]. This method allowed the identification of seven new mutations (Fig. 1), five being within the coding region. Amongst these mutations, two were missense mutations: the first mutation referred to as $\mathbf{S 1 0 5 C}$ resulted from a $\mathrm{C} \rightarrow \mathrm{G}$ transversion at coding nucleotide 314 in exon 1 and changed a Serine for a Cysteine found in the PA breed; the second mutation found in the MA breed and referred to as $D 182 N$ resulted in a $\mathrm{G} \rightarrow$ A transition at coding nucleotide 544 producing an amino acid change from Aspartic acid to Asparagine. Three other mutations were silent, two were identified in Exon 1 and referred to as $\boldsymbol{n t 2 6 7}$ (A $\rightarrow \mathrm{G}$ transition) and $\boldsymbol{n t 3 2 4}(\mathrm{C} \rightarrow \mathrm{T}$ transition) respectively, and the third $(\mathrm{G} \rightarrow \mathrm{A})$ called $\boldsymbol{n t 3 8 7}$ was found in Exon 2. All were found in the different French breeds: AU, BZ, SA for the first mutation, SA, AU, CH, IN95, MA for the second; the third mutation was found in different French and British breeds (AY, MA, SA, GL).

The other two new mutations located in the second intron and not affecting any coding sequence, were named $n t 747+7(G-A)$ and $n t 747+11(A-G)$ respectively, and were both found in British breeds. Most mutations described were transitions, so the average transition to transversion in the whole coding gene was 11:4. Transitions from $\mathrm{G}$ to $\mathrm{A}$ were more frequent (63\%) than from $\mathrm{C}$ to $\mathrm{T}(36 \%)$. The nucleotide differences rate along the $1764 \mathrm{nt}$ of the coding region including the splice sites was $10^{-2}$.

A total of twenty distinct haplotypes were unambiguously defined by using a standard PASA technique and are shown in Table II. Figure 1 shows the typical image of the simultaneous OLA screening for nine mutations involved in the most frequent haplotypes and which have been classified as being important to explain the different phenotypes. Since each primer used in this genotyping method was specifically labelled, the interpretation of the haplotype was very simple, each mutation being differentiated both by range and by colour as shown in Figure 1. Once the animals were genotyped using the SSCP analysis, all those with available phenotypic scores (a total of 505) were classified according to the four categories shown in Table III. In some breeds, e.g., RG, CH, GA, IN95 or MA, the phenotype was clearly explained by the myostatin genotype, but for a large number of individuals of the AV and PA breeds the observed phenotype was different from that expected from the genotype.

\section{DISCUSSION}

\subsection{New mutations}

The high level of polymorphism already described for the myostatin gene in humans [12] and cattle [15] was confirmed when a large number of individuals 
Table II. Haplotypes found in the myostatin gene when screening a total of 28 European bovine breeds.

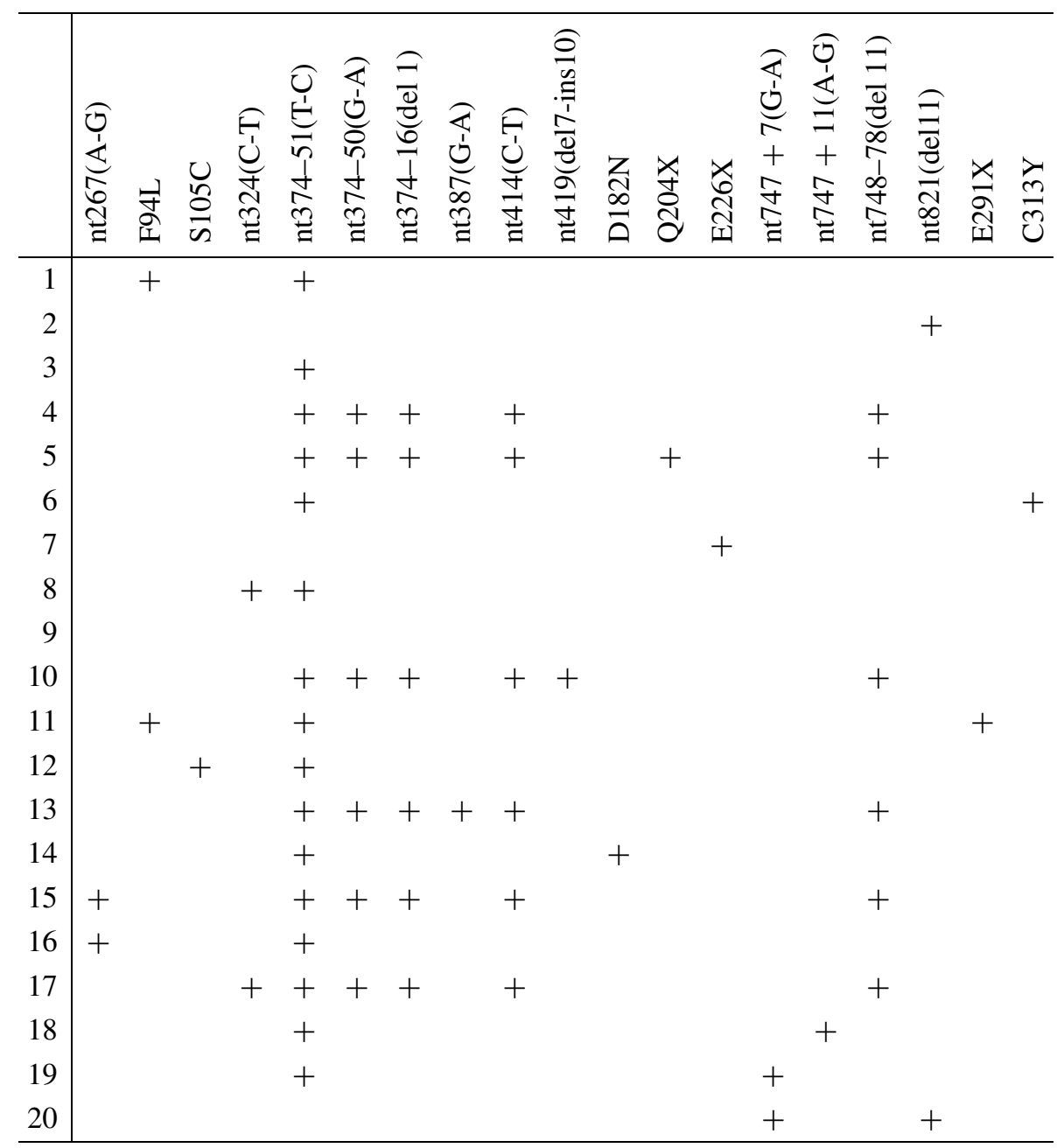

randomly sampled from different European bovine breeds were screened. The average number of SNP in human genes has been found to be 1 out of every 185 bases [37] and was larger here (1 out of every 100 bases) which suggests that the high level of polymorphism shown in this gene is the result of the selection of new occurring mutations thus increasing the variability at this locus.

All known mutations were identified and in addition seven new polymorphisms were described. Two of these were missense mutations in the first two exons, which are spliced into the mature peptide. Since myostatin is a member of the TGF $\beta$ family where nine cysteines are highly conserved across members 
Myostatin diversity in beef cattle

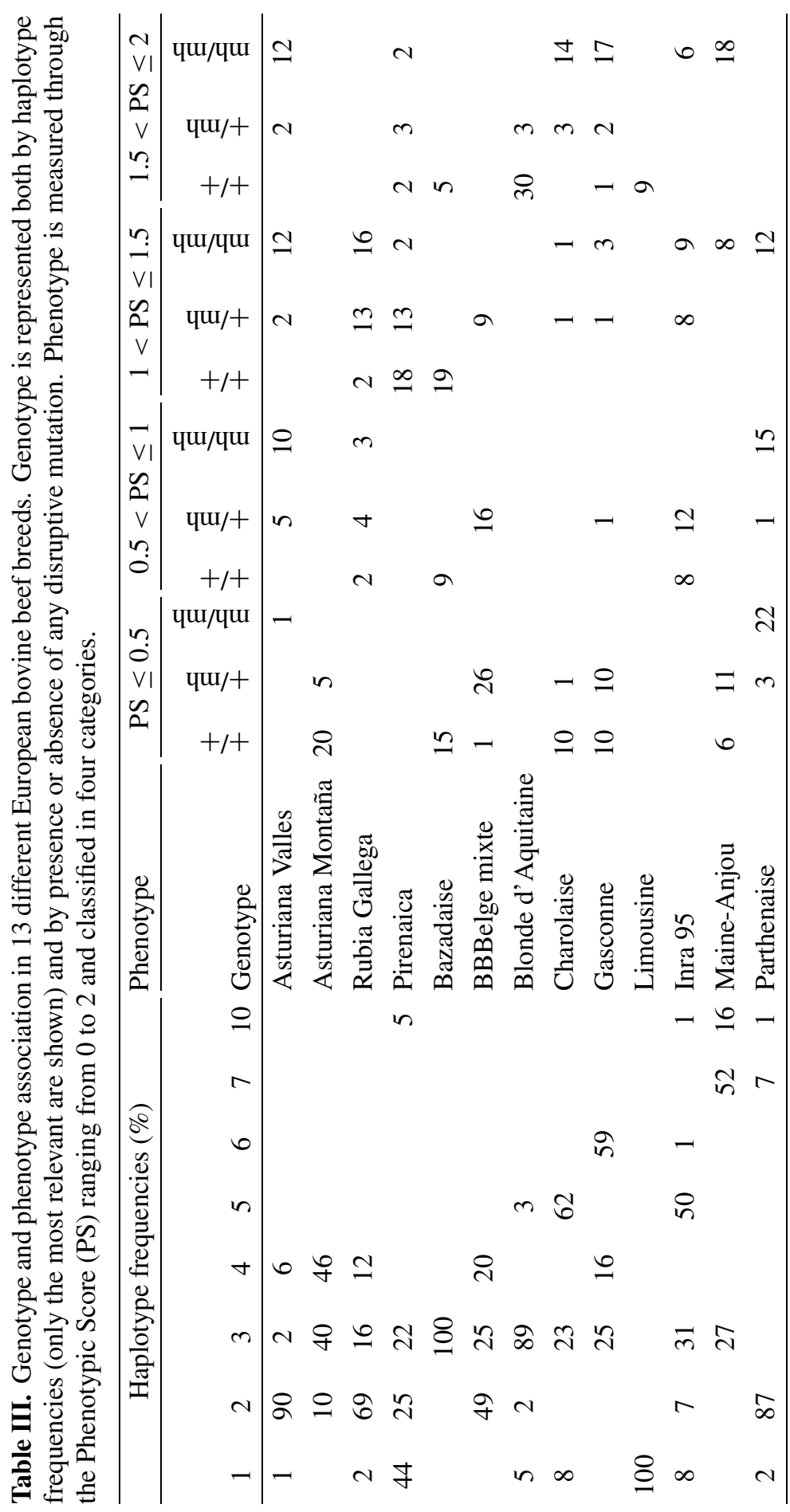


of the gene family and among species, it would be interesting to study the influence of the addition of a tenth cysteine residue in individuals carrying the $\mathrm{S} 105 \mathrm{C}$ mutation. The additional cysteine residue may influence intra- and interpeptide binding and have an effect on function and hence on the phenotype of the bearing individual (work currently in progress).

\subsection{OLA}

The OLA technique was set up according to the procedure of Grossman [16] and Karim [22], with some modifications which allowed flexibility to screen all different mutations as well as other polymorphisms which may be found in the future. Nine mutations (seven already described, $[4,15]$ and two mutations detected using the SSCP technique), were selected for screening by the OLA technique. From these mutations six were disruptive, and three produced an amino acid change affecting Exon 1 and 2. The reason for including these mutations was to confirm that when the protein adopts a particular structure, it will have a different activity which will result in a different phenotype.

\subsection{Haplotypes}

Grobet et al. (1998) [15] described the wild type as the haplotype lacking any mutation (haplotype 9 in this study) as found in the Holstein breed. However, here we found that the Holstein breed shows a significant high frequency of haplotype 4 (data not shown), in concordance with the results of Smith et al. (2000a) [34]. Moreover, haplotype 3 exclusively bearing the nt37451(T-C) mutation was found in $34 \%$ of the total meiosis analysed (Fig. 2) and should then be considered as the wild type allele, being much more frequent than haplotype 2 (26\% and the most frequent among disruptive haplotypes), haplotype $4(10.5 \%)$ and haplotype $9(1.5 \%)$. Also, it should be noted that the unique mutation present in haplotype 3 was found in nearly all breeds.

The disruptive haplotypes other than haplotype 2 were present in a much lower frequency across several breeds and some were exclusive of one or a few related breeds as is the case of haplotype 7 only found in the Maine-Anjou or haplotype 5 in the Charolaise. Some of the disruptive haplotypes were never associated with other mutations, for example nt821(del11) (haplotype 2) and E226X (haplotype 7) and also among the breeds, some haplotypes never combined ( 1 and 4 for example) or conversely were frequently found together (2 and 9) also indicating the history of the breeds. Some breeds showed a high polymorphism at the myostatin gene as for example PI probably due to its condition as a frontier breed intensively crossed with BA individuals, or the British LH breed [33] where a surprisingly high level of different haplotype combinations can be found in such a small breed. In other breeds however, 


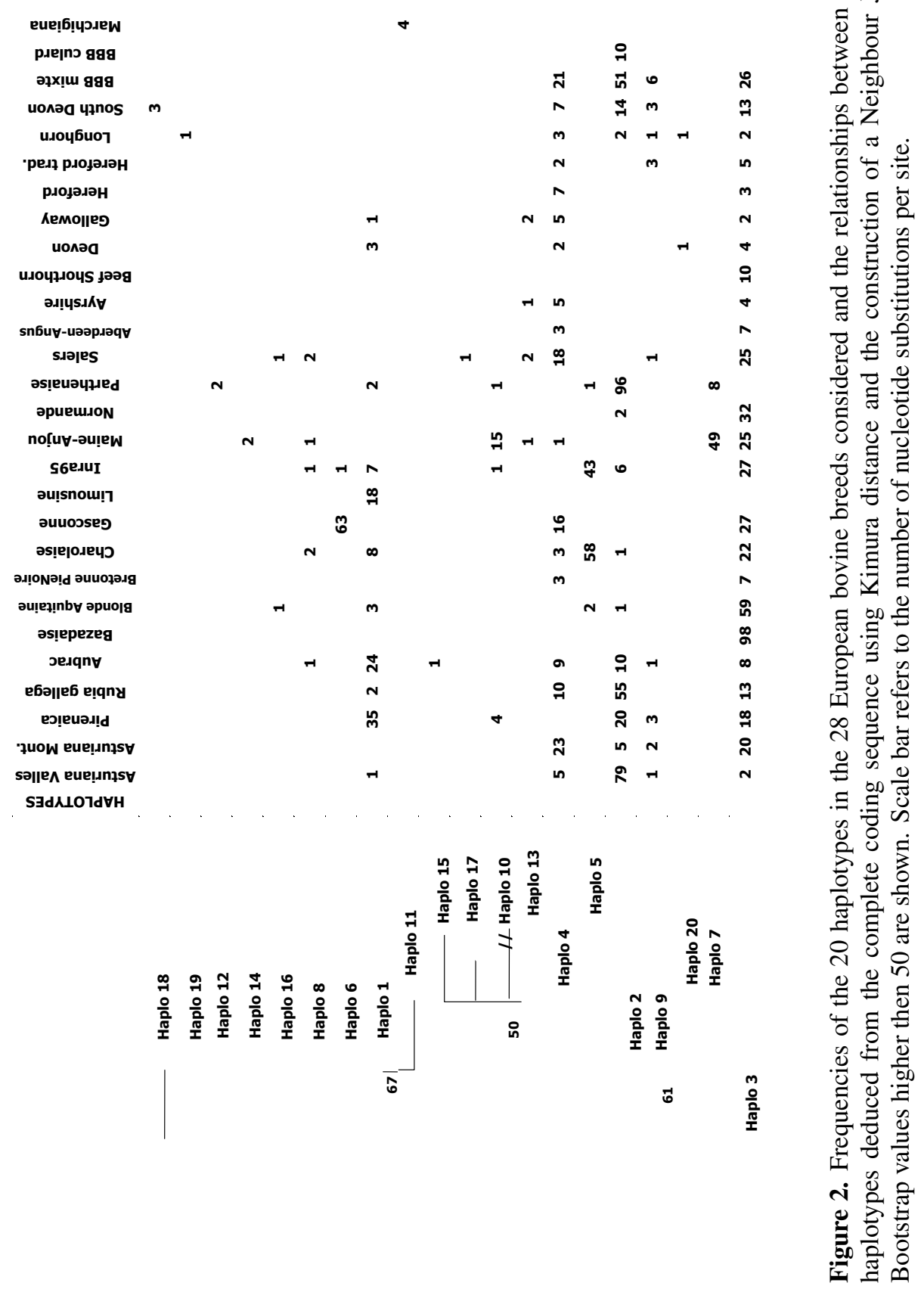


there was a very low variability (e.g., $\mathrm{CH}$ or GA), reflecting a high selection on this gene.

Rare haplotypes are more likely to be recently derived than those that are frequent [39], and if we observe the haplotype pairs 15 and 16, 8 and 17, 19 and 20 we will see that they share rare but also more common mutations; this can be the result of recombination events between existing haplotypes or show that some sites have undergone repeated mutational events (Fig. 2).

When observing the non-disruptive haplotypes, haplotype 1 appeared in the Aubrac, Limousine and Pirenaica breeds; the latter two breeds were surprisingly those in which most individual phenotypes are not explained by a disruptive mutation in the myostatin gene. This indicated a higher phenotypic influence than expected for a conservative mutation (work currently in progress).

\subsection{Introducing the phenotype}

The pattern of haplotype sharing is an indicator of the history of the different bovine populations, or breeds, so the distribution of shared haplotypes is very useful to investigating population relationships. In the last century, different explanations on the origin of the double-muscled phenotype in different continental beef breeds were proposed. One hypothesis is the extensive dissemination of individuals of the Shorthorn breed used in the late 19th century to improve most western European bovine breeds which would explain the presence of the trait $[10,25]$, and the other being the Friesian breed $[9,20,31]$ or more generally milk purpose black pied bovine populations from the Baltic plain (Hanset, pers. comm.), being responsible for spreading the mutation all over western Europe [25]. In order to test the hypothesis of the introduction of the double muscling alleles from a single breed, we studied the relationships between the different haplotypes deduced from the complete coding sequence, using the Kimura distance (which allows to consider transitions as well as transversions) and the construction of a Neighbour Joining tree (Fig. 2). The examination of these relationships between the haplotypes showed haplotype 3 as the wild type from which all mutations have arisen in four defined groups: the first cluster was missing intronic 374-51 (haplotypes 2, 9, 7 and 20); the second cluster groups haplotypes $4,5,10,13,15$ and 17 by sharing a set of intronic mutations found together (nt374-51, nt374-50, nt374-16 and nt414), a third group included haplotypes 1 and 11 , and finally the fourth was integrated by $19,12,18,14,6,8$ and 16. Among these four groups, one set of "old" haplotypes appeared at equivalent times, that is those integrating the last group and also 1,2 and 9, while haplotypes 7, 20, 4 and 11 arose later and more recently those haplotypes belonging to the second cluster, with 10 being the most recent (Fig. 2). 
The consideration of these relationships between haplotypes should make the evolution of the myostatin gene easier to understand. The existence of many different haplotypes that are not rooted in a common mutated ancestor seems to definitely refute a Shorthorn-Durham origin for the muscular hypertrophy phenotype. Although there was an important introduction of individuals belonging to this breed across Europe at the end of the 19th century and at the beginning of the 20th, especially in grassland (oceanic) territories, the analysis of the myostatin gene of this breed at the present indicates the lack of any mutation. However, the theory of a founder mutation (nt821(del11)) spreading from an epicentre localised in the Friesian or Black Pied breed, much before its large specialisation into milk production seems much more congruent. There is much evidence of a hypertrophic phenotype in this population [20,38] before the organisation of the breed and selection for high milk specialisation and before the migration of this population into several milk breeds, (e.g., Normande or Parthenaise) before 1950. It is important to note that during these years, most breeds in Europe were dual purposes, and they have only recently been selected specifically for beef or milk production. This can explain the introduction of haplotype 2 from the Friesian breed to dairy (Normande), and beef breeds (Aubrac, Blanc Bleu Belge, Parthenaise, Asturiana de Valles, and Rubia Gallega), after a large diffusion of this breed before the nineteen-fifties and later. In an attempt to improve the beef characters of some breeds, the selection of individuals that were heterozygotes for the disruptive mutation may have occurred through all northern and western Europe including Spain, France, the Netherlands, Belgium, Germany and Austria. For instance, the Moyennne and Haute Belgique breed, issued from this milk purpose population, became the Blanc Bleu breed through fixation of mutation nt821(del11) and later selection for $\boldsymbol{m} \boldsymbol{h}$ expression $[17,18]$. This phenomenon has been performed through different waves made evident when observing the large linkage disequilibrium found in Asturiana de Valles showing a more recent introduction [11]. Other breeds have been left apart from these migratory movements: this is the case for the Maine-Anjou, Charolaise and Gasconne located geographically in the French continental grasslands, in which particular mutations arose later with no spreading to the surrounding populations, or even in some cases (e.g., Limousine) have never appeared. According to this hypothesis, the results found for the British breeds were congruent since only individuals belonging to the South Devon showed a disruptive mutation corresponding to haplotype 2 which could have been introduced from exchanges with the Friesian or Black pied breed which have been highly documented in this country [20].

\subsection{Phenotype-genotype comparison}

When genotypes and phenotypic scores (Tab. III) are correlated, it seems most likely that other loci might play a role in the development of the double 
muscled phenotype. The high level of incomplete penetrance or variations in modifier genes present in some breeds like PA (37 individuals of 53) or AV (11 individuals of 44) showed that the expression of the muscular hypertrophy phenotype does not arise from a single disruptive mutation in a major gene. The high variability of phenotypic scores (ranging from 0 to 1.74 in the Charolais culard strain for example) seems to confirm $([11,15])$ the theory of a loci heterogeneity.

Given the high influence of the myostatin gene in the good muscular conformation of most European bovine beef breeds, and although there have been many efforts to identify other influencing genes and QTLs with smaller effects [5-7,35], it seems necessary to systematically screen most individuals in order to allow the management of this particular locus, and to possibly evaluate the effect of this and other genes in the phenotype.

\section{ACKNOWLEDGEMENTS}

This work was supported by EU demonstration project BIO4-CT98-0421 and CICyT AGF98-1087. We thank the Spanish, French and Belgium breeders associations for providing the samples.

\section{REFERENCES}

[1] Arthur P.F., Double muscling in cattle: a review, Aust. J. Agric. Res. 46 (1995) 1493-515.

[2] Bassam B.J., Caetano-Anollés G., Gresshoff P., Fast and sensitive silver staining of DNA in polyacrylamide gels, Anal. Biochem. 196 (1991) 80-83.

[3] Barroso A., Dunner S., Cañón J., Technical note: Detection of bovine Kappacasein variants $\mathrm{A}, \mathrm{B}, \mathrm{C}$ and $\mathrm{D}$ by means of polymerase chain reaction single strand conformation polymorphism (PCR-SSCP), J. Anim. Sci. 76 (1998) $1535-1538$.

[4] Cappucio I., Marchitelli C., Serracchioli A., Nardone A., Filippini F., AjmoneMarsan P., Valentini A., A G-T transversion introduces a stop codon at the mh locus in hypertrophic Marchigiana beef subjects. Abstracts of the XXVIth International Conference on Animal Genetics, 9-14 August 1998, Auckland, New Zealand.

[5] Casas E., Keele J.W., Shackelford S.D., Koohmaraie M., Sonstegard T.S., Smith T.P.L., Kappes S.M., Stone R.T., Association of the muscle hypertrophy locus with carcass traits in beef cattle, J. Anim. Sci. 76 (1998) 468-473.

[6] Casas E., Shackelford S.D., Keele J.W., Stone R.T., Kappes S.M., Koohmaraie M., Quantitative trait loci affecting growth and carcass composition of cattle segregating alternate forms of myostatin, J. Anim. Sci. 78 (2000) 560-569.

[7] Casas E., Stone R.T., Keele J.W., Shackelford S.D., Kappes S.M., Koohmaraie M., A comprehensive search for quantitative trait loci affecting growth and 
carcass composition of cattle segregating forms of the myostatin gene, J. Anim. Sci. 79 (2001) 854-860.

[8] Charlier C., Coppieters W., Farnir F., Grobet L., Leroy P., Michaux C., Mni M., Schwers A., Vanmanshoven P., Hanset R., Georges M., The mh gene causing double-muscling in cattle maps to bovine Chromosome 2, Mamm. Genome 6 (1995) 788-792.

[9] Dechambre, Les veaux à croupe de poulain, Rech. Méd. Vét., École Alfort, 88 (1911) 93-98.

[10] Denis B., Regards sur la «durhamisation» des bovins au XIX ${ }^{\mathrm{e}}$ siècle. Des leçons pour aujourd'hui, Renc. Rech. Ruminants, 7 (2000) 8-18.

[11] Dunner S., Charlier C., Farnir F., Brouwers B., Cañón J., Georges M., Towards interbreed IBD fine mapping of the mh locus: double-muscling in the Asturiana de los Valles breed involves the same locus as in the Belgian Blue cattle breed, Mamm. Genome 8 (1997) 430-435.

[12] Ferrel R.E., Conte V., Lawrence E.C., Roth S.M., Hagberg J.M., Hurley B.F., Frequent sequence variation in the human mysotatin (GDF8) gene as a marker for analysis of muscle-related phenotypes, Genomics 62 (1999) 203-207.

[13] González-Cadavid N., Taylor W., Yarasheski K., Sinha-hikim I., Ma K., Ezzat S., Shen R., Lalani R., Asa S., Mamita M., Nair G., Arver S., Bhasin S., Organization of the human myostatin gene and expression in healthy men and HIV-infected men with muscle wasting, Proc. Natl. Acad. Sci. USA 95 (1998) 14938-14943.

[14] Grobet L., Royo L., Poncelet D., Pirottin D., Brouwers B., Riquet J., Schoeberlein A., Dunner S., Ménissier F., Massabanda J., Fries R., Hanset R., Georges M., A deletion in the myostatin gene causes double-muscling in cattle, Nat. Genet. 17 (1997) 71-74.

[15] Grobet L., Poncelet D., Royo L., Brouwers B., Pirottin D., Michaux C., Ménissier F., Zanotti M., Dunner S., Georges M., Molecular definition of an allelic series of mutations disrupting the myostatin function and causing double-muscling in cattle, Mamm. Genome 9 (1998) 210-213.

[16] Grossman P.D., Bloch W., Brinson E., Chang C.C., Eggerding F.A., Fung S., Iovannisci D.M., Woo S., Winn-Deen E.S., High-density multiplex detection of nucleic acid sequences: oligonucleotide ligation assay and sequence-coded separation, Nucl. Acids Res. 22 (1998) 4527-4534.

[17] Hanset R., Michaux C., On the genetic determinism of muscular hypertrophy in the Belgian White and Blue cattle breed. I - Experimental data, Génét. Sél. Évol. 17 (1985a) 359-368.

[18] Hanset R., Michaux C., On the genetic determinism of muscular hypertrophy II.Population data, Génét. Sél. Évol. 17 (1985b) 369-386.

[19] Jean-Pierre M., A rapid method for the purification of DNA from blood, Nucl. Acids Res. 15 (1987) p. 9611.

[20] Kaiser, Uber die sogenannten doppellendigen Rinder, Ladw. Jbr. 17 (1888) 387-403.

[21] Kambadur R., Sharma M., Smith T.P.L., Bass J.J., Mutations in myostatin (GDF8) in double-muscled Belgian Blue Cattle, Genome Res. 7 (1997) 910-916.

[22] Karim L., Coppieters W., Grobet L., Valentini A., Georges M., Convenient genotyping of six myostatin mutations causing double-muscling in cattle using a multiplex oligonucleotide ligation assay, Anim. Genet. 31 (2000) 396-399. 
[23] Kimura M., A simple method for estimating evolutionary rate of base substitutions through comparative studies of nucleotide sequences, J. Mol. Evol. 16 (1980) 111-120.

[24] McPherron A.C., Lee S.J., Double muscling in cattle due to mutations in the myostatin gene, Proc. Natl. Acad. Sci. USA 94 (1997) 12457-12461.

[25] Ménissier F., Present state of knowledge about the genetic determination of muscular hypertrophy or the double muscled trait in cattle, in: King J.W.B., Ménissier F. (Eds.), Current Topics in Veterinary Medicine and Animal Science, Vol. 16: Muscle hypertrophy of genetic origin and its use to improve beef production, Martinus Nijhoff, 1982, pp. 387-428.

[26] Miranda M.E., Royo L., García-Atance P., Cañón J., Georges M., Ménissier F., Grobet L., Bosher M.Y., Dunner S., Análisis de la heterogeneidad alélica del gen de la miostatina en diferentes razas bovinas europeas. VIII Jornadas sobre Producción Animal. Zaragoza 11-13 de mayo, ITEA 20 (1999) 288-290.

[27] Miranda M.E., Cañón J., Ménissier F., Hanset R., Williams J., Dunner S., Identificación de los distintos haplotipos del gen de la miostatina en razas bovina europeas. (ITEA) IX Jornadas sobre Producción Animal. Volumen Extra, Número 22-Tomo I, 2001, pp. 39-41.

[28] Miranda M.E., Amigues Y., Boscher M.Y., Ménissier F., Cortés O., Dunner S., Simultaneous genotyping to detect myostatin gene polymorphism in beef cattle breeds, J. Anim. Breed. Genet. 119 (2002) 361-366.

[29] Orita M., Iwahana H., Kanazawa H., Hayashi K., Sekiya T., Detection of polymorphisms of human DNA by gel electrophoresis as single-strand conformation polymorphisms, Proc. Natl. Acad. Sci. USA 86 (1998a) 2766-2770.

[30] Orita M., Suzuki Y., Sekiya T., Rapid and sensitive detection of point mutations and DNA polymorphisms using the polymerase chain reaction, Genomics 5 (1998b) 874-879.

[31] Pyndt., Dobbeltlaarede Kalve. Maanedsskr. Dyrloeg. 19 (1907) 359-365.

[32] Sambrook J., Fritsch E.F., Maniatis T., Molecular cloning: a laboratory manual (2nd edn.), Cold Spring Harbor Laboratory Press, Cold Spring Harbor, NY, 1989.

[33] Simon D.L., Buchenauer D., Genetics of cattle diversity, EAAP (1993) Publication number 66.

[34] Smith J.A., Lewis A.M., Wiener P., Williams J.L., Genetic variation in the bovine myostatin gene in UK beef cattle: Allele frequencies and haplotype analysis in the South Devon, Anim. Genet. 31 (2000a) 306-309.

[35] Smith T.P.L., Casas E., Rexroad III C.E., Kappes S.M., Keele J.W., Bovine CAPN1 maps to a region of BTA29 containing a quantitative trait locus for meat tenderness, J. Anim. Sci. 78 (2000b) 2589-2594.

[36] Sommer S.S., Cassady J.D., Sobell J.L., Bottema C.D.K., A novel method for detecting point mutations or polymorphisms and its application to population screening for carriers of phenylketonuria, Mayo Clin. Proc. 64 (1989) 1361-1372.

[37] Stephens J., Schneider J., Tanguay D., et al., Haplotype variation and linkage disequilibrium in 313 genes, Science 293 (2001) 489-493.

[38] Thierry, Les veaux à cul de poulain, J. Agric. Prat., Paris 1 (1898) 182-184.

[39] Watterson G.A., Guess, H.A., Is the most frequent allele the oldest?, Theor. Popul. Biol. 11 (1977) 141-160. 